Отримано: 22 серпня 2018 р.

Прорецензовано: 02 вересня 2018 р.

Прийнято до друку: 10 вересня 2018 р. e-mail: opavelko@ukr.net

DOI: $10.25264 / 2311-5149-2018-10(38)-124-130$
Павелко О. В. Фактори впливу на величину прибутку будівельних підприємств. Наукові записки Національного університету «Острозька академія». Серія «Економіка» : науковий журнал. Острог : Вид-во НаУОА, вересень 2018. № 10(38). C. $124-130$.

\author{
Павелко Ольга Віталіївна, \\ кандидат економічних наук, доцент, доцент кафедри обліку і аудиту, \\ Національний університет водного господарства та природокористування
}

\title{
ФАКТОРИ ВПЛИВУ НА ВЕЛИЧИНУ ПРИБУТКУ БУДІВЕЛЬНИХ ПІДПРИЕМСТВ
}

У статті розглянуто фактори впливу на величину прибутку. Виокремлено фактори впливу на прибуток будівельних підприємств. Окреслено підходи науковиів до ідентифікаиії окреслених факторів впливу. Досліджено формування факторів впливу на створення прибутку будівельних підприємств у контексті інституційних змін. Висвітлено чинники інституційного середовища, щзо впливають на облікову систему. Проаналізовано основні форми трансакційних витрат. 3'ясовано відмінності між інституціональною теорією та неоінституціоналізмом.

Ключові слова: фактори, вплив, прибуток, будівельне підприємство, величина, інституиійні зміни.

\section{Павелко Ольга Витальевна,}

кандидат экономических наук, дочент, доцент кафедры учета и аудита,

Национальный университет водного хозяйства и природопользования

\section{ФАКТОРЫ ВЛИЯНИЕ НА ВЕЛИЧИНУ ПРИБЫЛИ СТРОИТЕЛЬНЫХ КОМПАНИЙ}

В статье рассмотрены факторы влияния на величину прибыли. Выделены факторы влияния на прибыль строительных предприятий. Определены подходы ученых к идентификации факторов влияния. Исследовано формирование факторов влияния на создание прибыли строительных компаний в контексте институциональных изменений. Освещены факторы институциональной среды, которые влияют на учетную систему. Проанализированы основные формы трансакциионных издержек. Выяснено различия между институциональной теорией и неоинституционализмом.

Ключевые слова: факторы, влияние, прибыль, строительное предприятие, величина, институциональные изменения.

\section{Olga Pavelko,}

PhD in Economics, Associated Professor at the Department of Accounting and Auditing, National University of Water and Environmental Engineering

\section{FACTORS OF INFLUENCE ON CONSTRUCTION ENTERPRISES PROFIT}

The factors of influence on profit are considered in the article. It was found out that a number of factors influence the size of financial results. The generalization of the approaches of scientists to identifying the factors of influence on profit gives grounds to declare that scientists traditionally distinguish external (macroeconomic, independent) and internal (microeconomic, dependent) factors of influence on the size of profit. The factors influencing the profit of construction enterprises are highlighted. Scientists' approaches to identifying the factors of influence are outlined.

It is substantiated that rationalization of the development process of the construction company accounting policy should be one of the priority tasks for the accounting staff, because correctly predicted elements that are objectively adapted to the needs of the economic entity make it is possible to increase the value of the financial result.

The formation of factors influencing the creation of construction enterprises profit in the context of institutional changes is investigated. The essence of institutional changes is analyzed. The factors of the institutional environment influencing the accounting system are highlighted. The basic forms of transaction costs are analyzed. The differences between the institutional theory and neo-institutionalism are found.

It is shown that the most generalized and adapted to the needs of construction contracts is the classification of transaction costs within periods (before, during and after the conclusion of contracts): ex-ante costs - arise up to the time of the exchange (costs of obtaining information on prices, quality of resources, business reputation of the counterparty, etc.); costs of ex-interim - appear in the exchange process (payment for insurance services, notarization of documents, conducting settlements, etc.); expenses of e-mail - arise after the exchange (costs for checking the execution of contracts, quality control, costs for the protection of contracts, etc.).

It has been established that the transaction cost savings are the basis for choosing the type of contract, in particular for building contracts. The participants in the construction process have the opportunity to sign a contract with a fixed price or contract of "cost plus".

Key words: factors, influence, profit, construction enterprise, size, institutional changes. 
Постановка проблеми. Основним джерелом фінансування розвитку господарюючих суб'єктів, найважливішим узагальнюючим показником та водночас ідентифікатором ефективності господарської діяльності є прибуток, що створюється під впливом низки факторів. Зважаючи на те, що за останні роки обсяги виконання будівельних робіт зростають, додаткових досліджень потребують фактори впливу на прибуток будівельних підприємств, у максимізації якого вони неабияк зацікавлені.

Управління прибутком полягає в прийнятті об'єктивних рішень, спрямованих на формування, розподіл і використання прибутку, і відповідно стратегічний розвиток підприємства. Можливість впливати на окреслені фактори дасть змогу нарощувати прибутковість діяльності і спрямовувати наявні ресурси на подальший розвиток будівельного підприємства. Отже, не викликає сумнівів актуальність нашого дослідження.

Аналіз останніх досліджень і публікацій. Теоретичну основу роботи склали праці вчених у галузі дослідження факторів, які чинять вплив на величину прибутку, зокрема: І. Ю. Єпіфанової [1], М. В. Патарідзе-Вишинської [2], М. М. Бердара [3], О. Г. Янкового [4], Е. Соколової [8]. Незважаючи на значні досягнення і напрацювання у цій сфері, питання щодо вивчення факторів впливу на величину прибутку будівельних підприємств залишаються недостатньо висвітленими і потребують додаткових наукових розвідок.

Мета статті полягає в ідентифікації факторів впливу на величину прибутку будівельних підприємств, для чого поставлено такі завдання: дослідити наявні фактори впливу на прибуток, виокремити фактори впливу на прибуток будівельних підприємств, висвітлити процесі формування факторів впливу на створення прибутку будівельних підприємств у контексті інституційних змін

Виклад основного матеріалу. На величину фінансових результатів чинить вплив низка факторів. Проведене узагальнення підходів науковців до ідентифікації факторів впливу на прибуток (збиток) дає підстави констатувати, що науковці традиційно виокремлюють зовнішні (макроекономічні, незалежні) та внутрішні (мікроекономічні, залежні) фактори впливу на розмір прибутку.

Внутрішні фактори поділяються на виробничі та невиробничі [1, с. 48; $2 ; 3$, с. 99], основні й неосновні [4, с. 300], інтенсивні й екстенсивні [2; 3 с. 99]; облікові фактори (об’єктивні й суб’єктивні) [5, с. 179]. Досить незвичною є класифікація, запропонована С. Н. Івашковським [6, с. 76], котрий здійснює розподіл факторів на три групи: у сфері виробництва; у сфері обігу; фактори, які не залежать від діяльності підприємства. Проте вона, на нашу думку, не дає можливості чітко ідентифікувати чинники впливу на прибуток, в повному обсязі оцінити сформовану ситуацію та на підставі одержаної інформації прийняти раціональні управлінські рішення.

У класифікації факторів, запропонованій О. Г. Янковим [4, с. 303-304], їх згруповано залежно від видів фінансових результатів: у розрізі прибутку від реалізації продукції, валового прибутку, прибутку від операційної, фінансової та інвестиційної діяльності. Водночас основними чинниками є доходи і витрати, які обліковуються на рахунках 7 і 9 класів відповідно. Звичайно, доходи і витрати є факторами, які чинять вплив на величину прибутку, адже при їх співставленні обчислюється фінансовий результат. Однак виникнення доходів і витрат обумовлюється окремими чинниками, які впливають на доходи і витрати, при співставленні яких обчислюється прибуток. Підсумовуючи вищевикладене, фактори впливу на прибуток будівельних підприємств пропонуємо виокремити у групи (рис. 1).

Вважаємо за доцільне виділити зовнішні (не залежать від діяльності підприємства) й внутрішні фактори (є пріоритетними при здійсненні впливу на величину прибутку). Внутрішні фактори впливу на величину прибутку будівельних підприємств слід класифікувати на виробничі і невиробничі, адже будівельне підприємство, крім ведення основної діяльності, може займатися іншими видами діяльності, де беруть участь невиробничі основні засоби.

Екстенсивні фактори чинять влив на розмір прибутку шляхом кількісних змін, інтенсивні - через якісні зміни. У процесі ведення діяльності будівельним підприємством перелічені фактори перебувають у тісному зв'язку і взаємозалежності, на що наголошено у працях: [7, с. $286 ; 8$, с. 357; 4, с. 302; 9, с. 150]. Наприклад, ціни на будівельні матеріали залежать від територіального розміщення постачальників, собівартість виконання будівельних робіт перебуває під впливом структури витрат та цін на будівельні матеріали, за якими вони купуються у постачальників. На використання в будівельному процесі сировини і матеріалів чинить вплив ритмічність поставок. Одним із важливих внутрішніх чинників величини прибутку є облікова політика підприємства. Як справедливо стверджує М. О. Бляхарчук, «...продумана облікова політика допоможе достовірно визначити прибуток, що дозволить заощадити на податкових платежах» [10, с. 27]. 


\begin{tabular}{|c|c|c|c|}
\hline \multicolumn{4}{|c|}{ Фактори впливу на величину прибутку будівельних підприємств } \\
\hline & \multicolumn{3}{|c|}{ I } \\
\hline Зовнішні & \multicolumn{3}{|c|}{ Внутрішні } \\
\hline & \multicolumn{2}{|l|}{$\downarrow$} & \\
\hline \multirow[b]{2}{*}{$\begin{array}{l}\text { - Рівень } \\
\text { інфляції; } \\
\text { - податкова } \\
\text { політика } \\
\text { держави; } \\
\text { - соціально- } \\
\text { економічні } \\
\text { умови; } \\
\text {-природно- } \\
\text { кліматичні } \\
\text { умови; } \\
\text { - кон'юнктура } \\
\text { ринку } \\
\text { трудових } \\
\text { ресурсів та } \\
\text { будівельних } \\
\text { організацій; } \\
\text { - нормативно- } \\
\text { правова база; } \\
\text { - наявна } \\
\text { конкуренція; } \\
\text {-ціни на } \\
\text { виробничі } \\
\text { ресурси. }\end{array}$} & \multirow{2}{*}{\multicolumn{2}{|c|}{$\begin{array}{l}\text {-Обсяги виконання будівельних робіт; } \\
\text { - вид будівництва; } \\
\text { - місце розташування об’єкта будівництва; } \\
\text { - технологічна складність об’єкта будівництва; } \\
\text { - спосіб фінансування будівництва; } \\
\text { - тривалість будівництва; } \\
\text { - кваліфікація працівників; } \\
\text { - забезпеченість ресурсами (матеріальними, } \\
\text { технічними, виробничими, фінансовими } \\
\text { інформаційними, людськими, природними) та } \\
\text { ефективність їх використання; } \\
\text {-собівартість виконання будівельних робіт; } \\
\text {-якість будівельних робіт; } \\
\text { - маркетингова діяльність; } \\
\text {-порушення умов праці, стандартів та норм; } \\
\text {-конкурентоспроможність; } \\
\text { - продуктивність праці; } \\
\text {-форми і системи економічного стимулювання; } \\
\text { - моральний і фізичний знос основних засобів; } \\
\text {-порядок ціноутворення; } \\
\text {-стан та ефективність фінансового планування; } \\
\text {-механізм інкасації дебіторської заборгованості; } \\
\text {-облікова політика. }\end{array}$}} & Оольковь \\
\hline & & & $\begin{array}{l}\text { - Критерії включення об’єкта до } \\
\text { складу основних засобів, } \\
\text { малоцінних необоротних } \\
\text { активів; } \\
\text { - способи нарахування } \\
\text { амортизації на основні засоби, } \\
\text { інші необоротні матеріальні } \\
\text { активи, нематеріальні активи; } \\
\text { - методи переоцінки основних } \\
\text { засобів, нематеріальних } \\
\text { активів; } \\
\text { - методи оцінки виробничих } \\
\text { запасів, незавершеного } \\
\text { виробництва; } \\
\text {-метод створення резерву } \\
\text { сумнівних боргів; } \\
\text { - методи оцінки ступеня } \\
\text { завершеності робіт; } \\
\text { - методи обліку витрат на } \\
\text { виробництво; } \\
\text {-механізм розподілу } \\
\text { загальновиробничих витрат; } \\
\text {-порядок калькулювання } \\
\text { собівартості. }\end{array}$ \\
\hline \multicolumn{4}{|c|}{ I } \\
\hline \multicolumn{2}{|r|}{ Виробничі } & \multicolumn{2}{|r|}{ Невиробничі } \\
\hline & \multicolumn{2}{|r|}{$\downarrow$} \\
\hline \multicolumn{2}{|c|}{$\begin{array}{l}\text { - Наявність активів, які беруть } \\
\text { безпосередню участь у будівництві, } \\
\text { ефективність їх використання, ступінь } \\
\text { зносу; } \\
\text { - продуктивність праці при здійсненні } \\
\text { будівництва тощо. }\end{array}$} & \multicolumn{2}{|c|}{$\begin{array}{l}\text { - Наявність активів, які не беруть безпосередню } \\
\text { участь у будівництві, ефективність їх } \\
\text { використання, ступінь зносу; } \\
\text { - продуктивність праці при здійсненні } \\
\text { неосновної діяльності будівельного } \\
\text { підприємства тощо. }\end{array}$} \\
\hline \multicolumn{2}{|r|}{ Екстенсивні } & \multicolumn{2}{|r|}{ Інтенсивні } \\
\hline \multicolumn{2}{|r|}{ 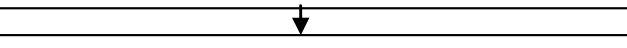 } & \multicolumn{2}{|r|}{$\downarrow$} \\
\hline \multicolumn{2}{|c|}{$\begin{array}{l}\text { - } \text { Зміна чисельності працівників; } \\
\text { - } \text { зміна тривалості робочого дня; } \\
\text { - } \text { втрати через відходи сировини і матеріалів } \\
\text { тощо. }\end{array}$} & \multicolumn{2}{|c|}{$\begin{array}{l}\text { - Підвищення кваліфікації працівників; } \\
\text { - } \text { впровадження прогресивних технологій; } \\
\text { - } \text { зміна продуктивності устаткування; } \\
\text { - } \text { удосконалення організації праці тощо. }\end{array}$} \\
\hline
\end{tabular}

Рис. 1. Фактори впливу на величину прибутку будівельних підприсмств*

*Розроблено автором.

О. М. Костенко наголошує на тому, що «...від облікової політики може залежати і прибутковість» $[11$, с. 72]. Цієї ж думки дотримуються І. Жиглей, В. Кузь, О. Лаговська, О. Олійник [5, с. 180], Ф. Бутинець $[12$, с. 292], С. Голов [13, с. 205], П. Житний [14, с. 19], Н. Кондраков [15, с. 7], С. Бичкова, Н. Макарова [16, с. 226], А. А. Єфремова [17, с. 82].

Нині суб'єкти господарювання мають змогу самостійно визначати основні положення облікової політики, враховуючи водночас базові принципи ведення бухгалтерського обліку, передбачені чинною нормативно-правовою базою. Саме в наказі про облікову політику будівельного підприємства визначаються критерії включення об'єкта до складу основних засобів, малоцінних необоротних активів; способи на- 
рахування амортизації на основні засоби, інші необоротні матеріальні активи, нематеріальні активи; методи переоцінки основних засобів, нематеріальних активів методи оцінки виробничих запасів, незавершеного виробництва; створення резерву сумнівних боргів; методи оцінки ступеня завершеності робіт; методи обліку витрат на виробництво; механізм розподілу загальновиробничих витрат; порядок калькулювання собівартості; механізм визнання доходу тощо. Перераховані позиції належать до облікових факторів впливу на величину прибутку будівельного підприємства, які затверджуються керівництвом господарюючого суб'єкта і безпосередньо пов'язані з процесом управління.

Однак слід відмітити й можливість маніпулювання окремими об'єктами за допомогою окреслених чинників, на що вказує І. Й. Яремко: «Традиційна бухгалтерія у своїй теорії та практиці з орієнтацією на поточний прибуток з математичними алгоритмами позбавили економічної природи переважну більшість облікових об’ єктів» [20, с. 22].

Отже, раціоналізація процесу розробки облікової політики будівельного підприємства має бути одним iз пріоритетних завдань працівників бухгалтерії, адже завдяки правильно передбаченим ії елементам, які об'єктивно адаптовані під потреби господарюючого суб'єкта, уможливлюється підвищення значення фінансового результату. Враховуючи те, що на величина прибутку залежить від зовнішніх факторів, доцільно акцентувати увагу на впливі інституційної економічної теорії на методологію обліку фінансових результатів. Проблемам удосконалення обліку шляхом використання інституційного інструментарію присвячено праці В. М. Жука, Н. А. Лоханової, С. Ф. Легенчука, І. В. Жиглей, В. І. Кузь, О. А. Лаговської, О. В. Олійник, В. В. Панкова, М. А. Проданчук, І. Б. Садовської, Н. В. Семенишеної, І. А. Юхименко-Назарук, В. Семанюк та ін.

З позиції Р. Ф. Пустовійта під інституціональними змінами слід розуміти «сутнісні та кількісно-якісні перетворення соціально-економічних інститутів» [21, с. 13]. Формування факторів впливу на прибуток будівельних підприємств в контексті інституційних змін зображено на рис. 2. Під впливом трансформації економіки відбулася зміна правил господарювання у вигляді інституційних (інституціональних) перетворень (змін), внаслідок чого виникла інституційна (інституціональна) теорія та неоінституційна (неоінституціональна) теорія.

«Інституціональна зміна визначає шлях, яким суспільство розвивається в часі, i тому є ключем до розуміння історичної зміни», - вважає Д. Норт [24, с. 10]. Поява інституціоналізму (кінець 19-початок 20 ст.) спричинена трансформаційними зрушеннями в ринковій системі, на які справила вплив монополізація економіки, незадоволеність традиційною економічною теорією, прояв ринкової нестабільності, посилення впливу профспілкового та робітничого руху, наявність соціальних суперечностей, виникнення потреби у суспільному контролі над ринковим механізмом, необхідність вирішення соціально-економічних проблем. Об'єктами дослідження виступали такі інститути, як держава, корпорації, профспілки, політичні партії, а також традиції, звичаї, способи мислення, навички, тобто моральні та етичні аспекти.

Аналіз праць за вказаною тематикою [25, с. 430; 26, с. 365, 27; с. 20-21; 28, с. 34] дає підстави стверджувати, що спільним в поглядах науковців є виокремлення неоінституціоналізму як нової інституційної теорії та розкриття основних концепцій, які формують іiі змістове ядро наповнення. Обидві теорії ідентифікують базові основи розвитку економічної й соціальної сфер через встановлення взаємозв'язків між інститутами, що чинить вплив на процес формування фінансових результатів, їх відображення в обліку.

В інституційному (інституціональному) середовищі існують формальні та неформальні інститути. Формальними є ті правила, механізми, які передбачені нормативно-правовими актами, неформальними загальноприйняті норми поведінки людей (традиції, звичаї, моральні цінності). Інституційне середовище формує інституційні зміни і навпаки: зміни впливають на інституційне середовище.

Основними чинниками зовнішнього інституційного середовища є податкова політика, нормативноправова база, в тому числі та, що регламентує методологію визначення фінансових результатів, інформаційно-консультаційне забезпечення, масштаби тіньової економіки, науково-технічний прогрес, глобалізація тощо. Правила реальної облікової практики встановлюються внутрішнім середовищем, основними чинниками при цьому виступають система регламентації облікових процесів, включаючи облікову політику, внутрішня організаційна структура бізнесу, поведінкові мотиви працівників підприємства та користувачів звітності.

Підтримуючи позицію Т. Сльозко [29, с. 89], зауважимо, що чинники інституційного середовища, які впливають на облікову систему, доцільно розділяти на чинники об'єктивного (існують об'єктивно) і суб'єктивного характеру (залежать від дій конкретних людей, котрі належать до окремих інститутів). Відтак, чинники справляють вплив на інституційні зміни, від яких залежить інституційне середовище, під дією якого формуються фактори впливу на величину різних видів прибутку. Ці фактори впливають $і$ на розмір трансакційних витрат. Зазначене поняття вперше було запропоноване Р. Коузом, під якими він розумів витрати на функціонування ринку.

Наукові записки Національного університету «Острозька академія», серія «Економіка», № 10(38), вересень, 2018 р. 


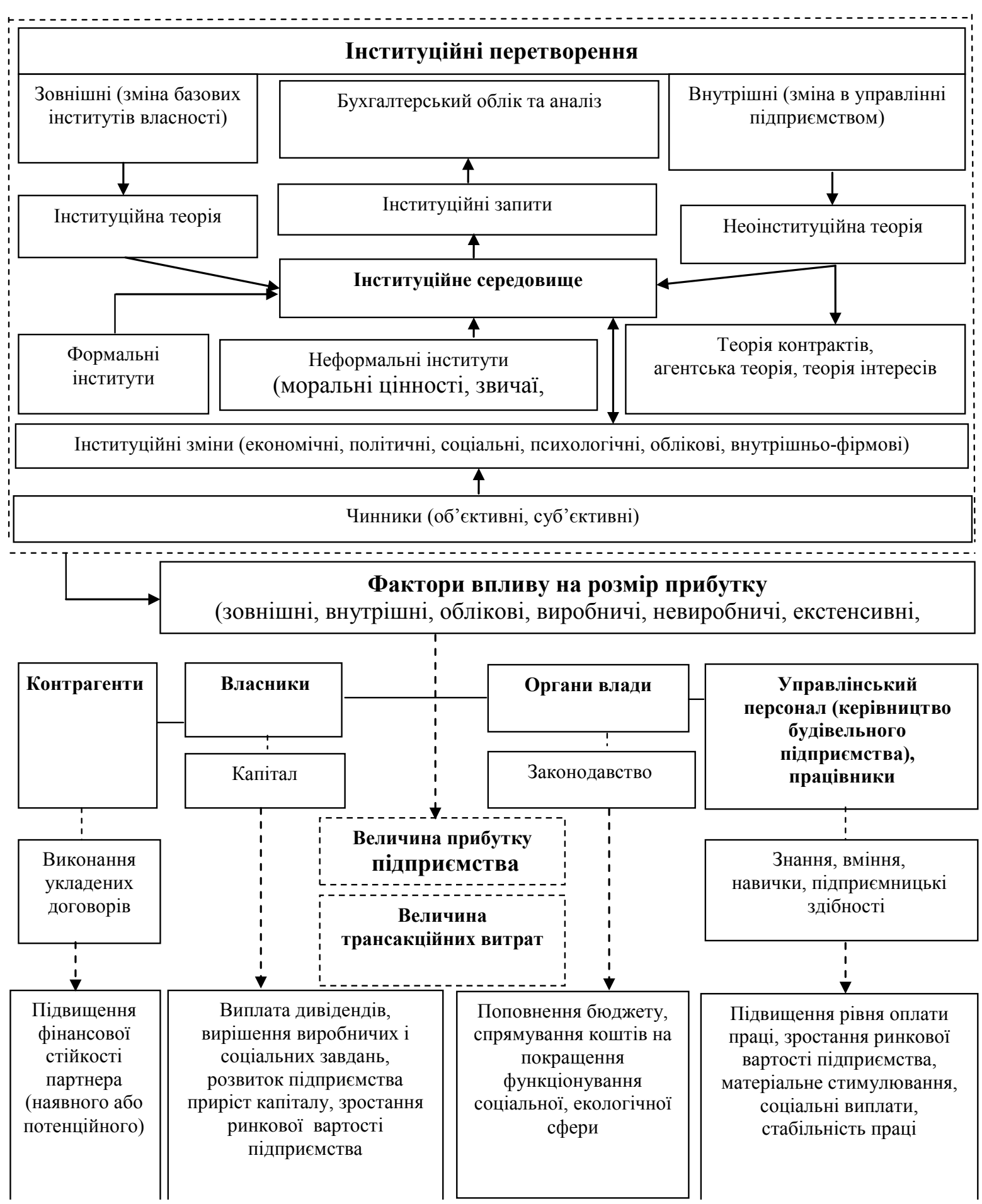

Рис. 2. Формування факторів впливу на створення прибутку будівельних підприємств у контексті інституційних змін

*Складено автором за даними: [22, с. 215; 23, с. 430].

Основні форми трансакційних витрат представлено в таблиці 1. Сучасні економісти загалом пропонують значний перелік видів трансакційних витрат: у дослідженнях О. Вільямсона акцент поставлено на витратах опортуністичної поведінки, Дж. Стіглер звертає увагу на витрати отримання інформації, М. Дженсен та У. Меклінг більш поглиблено розглядають витрати у межах відносин «principal-agent», Й. Барцель наголошує на існуванні витрат вимірювання, А. Алчіан і Г. Демсетс констатують про наявність витрат на координацію між різноманітними ресурсами у процесі виробництва. 
Таблиия 1

Основні форми трансакційних витрат

\begin{tabular}{|c|c|c|c|c|c|}
\hline $\begin{array}{l}\text { № } \\
\text { 3/II }\end{array}$ & Фактори впливу & $\begin{array}{c}\text { 3a Р. Коу- } \\
\text { зом, В. В. } \\
\text { Козюк } \\
{[30, \text { c. 570] }}\end{array}$ & $\begin{array}{c}\text { За К. Мена- } \\
\text { ром, В. Д. } \\
\text { Базилевич } \\
\text { [31, с. 514] }\end{array}$ & $\begin{array}{l}\text { За Д. Нор- } \\
\text { том, В. Д. } \\
\text { Базилевич } \\
{[31, \text { с. 514] }}\end{array}$ & $\begin{array}{c}\text { За О. Вільям- } \\
\text { соном, В. Д. } \\
\text { Базилевич } \\
\text { [31, с. 516] }\end{array}$ \\
\hline 1. & Витрати на пошук інформації & + & + & & + \\
\hline 2. & Витрати на здійснення переговорів та укладання контрактів & + & & & + \\
\hline 3. & Витрати виміру & + & & + & + \\
\hline 4. & Витрати специфікації та захисту прав власності & + & & & \\
\hline 5. & Витрати опортуністичної поведінки & + & + & & + \\
\hline 6. & Витрати на виділення & & + & & \\
\hline 7. & Витрати на масштаб & & + & & \\
\hline 8. & Витрати на захист прав & & & + & + \\
\hline 9. & Витрати на нагляд за дотриманням угод & & & + & \\
\hline 10. & Витрати на забезпечення виконання угод & & & + & \\
\hline 11. & Витрати ex ante & & & & + \\
\hline 12. & Витрати ex post & & & & + \\
\hline
\end{tabular}

У дисертаційній роботі В. Диби [32] трансакційні витрати виділено за ознаками контрольованості, етапів транзакції, об’єктивності виникнення, залежно від моменту укладання контракту і запропоновано узгодженість ринкових трансакційних витрат з витратами діяльності з урахуванням вимог ПСБО 16 «Витрати» та Плану рахунків бухгалтерського обліку.

Висновки. Найбільш узагальненою і пристосованою під потреби будівельних контрактів $\epsilon$ класифікація трансакційних витрат у межах періодів (до, під час і після укладання контрактів):

- витрати ex-ante - виникають до моменту проведення обміну (витрати на одержання інформації про ціни, якість ресурсів, ділову репутацію контрагента тощо);

- витрати ex-interim - з'являються у процесі обміну (плата за страхові послуги, нотаріальне посвідчення документів, проведення розрахунків тощо);

- витрати ex-post - виникають після обміну (витрати на перевірку виконання контрактів, контроль за якістю, витрати на захист контрактів тощо).

Таким чином, згідно з неоіституційною теорією саме економію трансакційних витрат покладено в основу вибору типу контракту, зокрема що стосується будівельних контрактів, то в учасників будівельного процесу є можливість укладання контракту з фіксованою ціною або контракту за ціною «витрати плюс». Учасники будівельного процесу, діючи в межах контрактної теорії (contract theory), намагаються мінімізувати витрати і максимізувати прибуток, що може бути різних видів, зважаючи на низку наявних класифікаційних ознак.

Подальшим напрямом наукових розвідок щодо нашого питання буде вивчення класифікацій прибутку будівельних підприємств, що формується під впливом низки факторів.

\section{Література:}

1. Єпіфанова І. Ю., Гуменюк В. С. Фактори зростання прибутку підприємства. Молодий вчений. 2016. № 7(34). C. 46-49.

2. Патарідзе-Вишинська М. В. Прибуток підприемств: види, роль та функції. Економіка. Управління. Інноваціï. 2010. № 1. C. 48-55.

3. Бердар М. М. Фінанси підприємств: навч. посіб. К. : Центр учб. літератури, 2010. 352 с.

4. Янковий О. Г., Кошельок Г. В. Фактори формування прибутку підприємства. Вісник соиіально-економічних досліджень. 2011. Вип. 3(43). С. 298-305.

5. Розвиток бухгалтерського обліку в контексті узгодження антагоністичних інтересів груп заінтересованих осіб: монографія / І. В. Жиглей, В. І. Кузь, О. А. Лаговська, О. В. Олійник. Чернівці: Технодрук, 2012. 248 с.

6. Ивашковский С. Н. Экономика: Микро и макроанализ: [учебно-практ. пособ.]. М.: Дело, 1999. 360 с.

7. Продиус Ю. И. Экономика предприятия. Одесса: Черноморье, 2002. 414 с.

8. Соколова Е., Щербак А. Особливості формування фінансових результатів суб’єктів господарювання та забезпечення управління прибутками вітчизняних підприємств. Зб. наук. праџь ДЕТУТ. Серія «Економіка $i$ управління». 2015. Вип. 33. С. 352-362.

9. Фінансовий менеджмент: навч. посіб. [за ред. проф. Г.Г. Кірейцева]. Київ: ЦУЛ, 2002. - 496 с.

10. Бляхарчук М. О. Формування облікової політики в системі управління підприємством: дисертація на здобуття наукового ступеня кандидата економічних наук, спец. 08.00.09 - бухгалтерський облік, аналіз та аудит (за видами економічної діяльності), Луцький національний технічний університет. 2016. 304 с.

11. Костенко О. М. Облікова політика як внутрішньогосподарський інструмент впливу на формування прибутковості підприємства. Економіка та держава. 2009. № 6. С. 71-72. 
12. Бутинець Ф. Ф. Теорія бухгалтерського обліку: підручник [для студентів спеціальності 7.050106 «Облік i аудит» вищих навчальних закладів]. [3-т. вид., доп. і перероб.]. Житомир: ПП «Рута», 2003. 444 с.

13. Голов С. Ф. Бухгалтерський облік в Україні: аналіз стану та перспективи розвитку: монографія. Київ: Центр учбової літератури, 2007. 522 с.

14. Житний П. І. Проблеми формування облікової політики та шляхи її вирішення. Бухгалтерський облік $i$ aydum. 2005. - № 3. С. 19-22.

15. Кондраков Н. П. Учетная политика организации. М.: Главбух, 1999. 136 с.

16. Бычкова С. М., Н. Н. Макарова. Бухгалтерское дело: [учеб пособие]. М.: Эксмо, 2008. 336 с.

17. Ефремова А. А. Учетная политика предприятия: содержание и формирование. М.: Финансы и статистика, $2002.640 \mathrm{c}$.

18. Сльозко Т. Оцінка об’єктів: необхідність пошуку єдиної норми. Теорії мікр-макроекономіки: зб.наук. праиь. 2010. № 34. C. 183-191.

19. Slyozko T. M. Cost estimation problems of objects. Quantative methods in finance and accounting; Wroclaw university of economics. Wroclaw, 2008. P. 113-119.

20. Яремко І. Й. Економічні категорії в методології обліку. Львів: Каменяр, 2002. 192 с.

21. Пустовійт Р. Ф. Вплив державної політики на процес інституціональних змін. Економічна теорія. 2006. № 1. С. 13-23.

22. Павленко Р. В. Теорії прибутку минулого сторіччя. Формування ринкових відносин в Украӥні: зб. наук. прайb. 2001. № 1-2. С. 215-216.

23. Башнянин Г. І., Лазур П. Ю. Політична економія. Ч.1; Ч.2: Загальна економічна теорія; Спеціальна економічна теорія: підруч. для студ. екон. вищ. навч. закл. К.: Ніка-Центр; Ельга, 2002. 527 с.

24. Норт Даглас. Інституції. Інституціональна зміна та функціонування економіки / пер. $з$ англ. І. Дзюб. Київ: Основи, 2000. -198 с.

25. Історія економіки та економічної думки: навч. посіб. / Козюк В.В., Родіонова Л.А. Тернопіль, ТзОВ» Техно-граф», 2010. 624 с.

26. Фуруботн Э. Г., Рихтер Р. Институты и экономическая теория: достижения новой институциональной экономической теории. Пер. с англ. под ред. В.С. Катькало, Н. П. Дроздовой. СПб.: Издат. дом С.-Петерб. гос. ун-та, 2005. 702 с.

27. Эггерстон Т. Экономическое поведение и институты / Пер. с. англ. М.: Дело, 2001. 408 с.

28. Юхименко-Назарук I. А. Розвиток теорії та методології бухгалтерського обліку в контексті неоінституційної теорії: дисертація на здобуття наукового ступеня доктора економічних наук за спеціальністю 08.00.09 - бухгалтерський облік, аналіз та аудит (за видами економічної діяльності). Житомир, 2017. 456 с.

29. Сльозко Т. Розвиток бухгалтерського обліку в інституційному середовищі. Вісник КНТЕУ. 2012. № 3. C. $84-93$.

30. Історія економіки та економічної думки: навч. посібник / Козюк В.В., Родіонова Л.А. Тернопіль, ТзОВ» Техно-граф», 2010. 624 с.

31. Історія економічних учень: Підручник: У 2 ч. - Ч. 1 / За ред. В.Д. Базилевича. 2-ге вид., випр. Київ: Знання, 2005. $567 \mathrm{c.}$

32. Диба В. М. Облік та аналіз нематеріальних активів в умовах інституційних змін: теорія і методологія: дисертація на здобуття наукового ступеня доктора економічних наук, спеціальність 08.00.09- бухгалтерський облік, аналіз та аудит (за видами економічної діяльності), ДВНЗ «Київський національний економічний університет імені Вадима Гетьмана», Київ, 2017. 466 с. 